ORIENTAL JOURNAL OF CHEMISTRY

An International Open Free Access, Peer Reviewed Research Journal

\title{
The Synthesis of Ag Nanoparticles and Loading in on Activated Carbon as A Novel Adsorbent for Removing Methyl Orange by Using Surface Response Methodology
}

\author{
S. JAVAD HOSSEINI ${ }^{1}$, H. AGHAIE ${ }^{1 *}$ and M.GHAEDI ${ }^{2 *}$ \\ ${ }^{1}$ Department of Chemistry, Tehran Science and Research Branch, Islamic Azad University, Tehran, Iran \\ ${ }^{2}$ Department of Chemistry, Yasouj University, Yasouj, Iran \\ http://dx.doi.org/10.13005/ojc/300449
}

(Received: August 10, 2014; Accepted: September 26, 2014)

\begin{abstract}
After synthesizing Ag nanoparticles and loading onto activated carbon (from olive stone), the adsorption of methyl orange (MO) onto the prepared nanoparticles was studied. In this connection, the effect of experimental parameters such as $\mathrm{pH}$ range, reagent concentration, contact time, dosage amount of adsorbent and so on, on the adsorption process were studied. The experimental results were analyzed upon various kinetic models such as pseudo first order reaction, pseudo second order reaction, Elovich model, intraparticle diffusion model and various adsorption isotherms such as Langmuir isotherm, Freundlich isotherm and Temkin isotherm.
\end{abstract}

Key words: Adsorption, Ag Nanoparticle, Isotherm, Activated carbon

\section{INTRODUCTION}

Anionic dyes may be toxic, carcinogenic and even mutagenic and generate serious hazards to aquatic living organisms and ecosystems 1 7.Biodegradation is a difficult task and required great attention and emphasis potential. Many studies have been carried out on adsorption of organic anionic dyes by various adsorbents8,10. Of the dyes, the water-soluble reactive and acid dyes are the most problematic because of their tendency of passing through conventional treatment systems without affectability 11-15.Recently removal of dyes through adsorption on activated carbon(AC) has been found to be very effective16 but fairly high cost limits its application 17 .

Methyl Orange (MO) as a water-soluble azo dye (well-known carcinogenic organic substance) widely is used in textile, printing, paper manufacturing, pharmaceutical and food industries but also in research laboratories as an acid base indicator due to its ability to function as a weak acid (Schem 1)18. 
Microbial succession and intestinal enzyme activities in developing rats have also been studied about MO19, and it was found that this dye can increase nitro and azo reduce activities significantly, with the appearance of anaerobes in the large intestine. Always, this dye, entering the body through ingestion, metabolizing into aromatic amines by intestinal microorganisms. Reductive enzymes in the liver can also catalyze the reductive cleavage of the azo linkage to produce aromatic amines, and can even lead to intestinal cancer ${ }^{20,21}$. $\mathrm{MO}$ is a representative contaminate in industrial wastewater and shows poor biodegradability ${ }^{22}$. Various physical, chemical and biological methods including adsorption ${ }^{23-25}$, oxidation or ozonation ${ }^{26,}$ ${ }^{27}$, membrane separation ${ }^{28}$, biodegradation29, coagulation and flocculation30 are available for removing MO. Adsorption over a surface with highly ionic character is mostly effective and very fast for removing a dye with opposite ionic character31. Adsorption techniques have a good potential for removing organics from water due to their high efficiency and ability to separate a wide range of chemical compounds ${ }^{32-34}$. Metal nanoparticles (MNPs) have a wide range of applications in science, technology, and medicine ${ }^{35}$. It is a well-known that silver ions and silver-based compounds are highly toxic to microorganisms which include 16 major species of bacteria ${ }^{36,37}$. There are many ways reported in various literatures to synthesize silver nanoparticles ${ }^{49}$. These include physical, chemical, and biological methods.

The physical and chemical methods are numerous but some of these methods are expensive or use toxic substances which are major factors that make them "not so favored. An alternate, feasible method to synthesize silver nanoparticles is to employ biological methods by using microbes and plants38. In this work we used the green synthesis for producing the Ag nanoparticles, Ag-NPs, by using the soluble starch as reducing agent. The green synthesis of Ag NPs involves three main steps, which must be evaluated based on green chemistry perspectives, including: (1) selection of solvent medium, (2) selection of environmentally benign reducing agent, and (3) selection of nontoxic substances for the Ag-NPs stability39, 40.

The present work at first focuses on the effects of operating parameters which affect on $\mathrm{Ag}$ NPs synthesis, such as $\mathrm{pH}$, time of reaction, initial silver nitrate concentration and starch concentration and in the second step, on the analysis of effective parameters on the dye adsorption by Response Surface Methodology (RSM). Our purpose is: (i) to better understand the relationship between the affective factors and the response (the capacity of the adsorption); and(ii) to determine the optimum conditions for the next step of dye adsorption onto synthesized silver nanoparticles loaded on activated carbon (Ag-NPs-AC).

\section{EXPERIMENTAL}

\section{Materials and methods}

All chemicals including $\mathrm{NaOH}, \mathrm{HNO}$, starch and other reagents, with the highest available purity were purchased from Merck, Darmstadt, Germany. MO was used as received without any further purification; while its color was stable under experimental conditions. A stock solution of $\mathrm{MO}$ was prepared by dissolving its required amount in distilled water and the working solutions with desired concentrations were prepared by successive dilutions of the stock solution. The concentration of the dye was determined at $412 \mathrm{~nm}$ using Jusco UV-Visible spectrophotometer model $\mathrm{V}-530$, while the $\mathrm{pH}$ was adjusted and measured by $\mathrm{pH} / \mathrm{lon}$ meter model-686, metrohm.

\section{Preparation of silver nanoparticles}

The aqueous solutions of silver nitrate and starch were prepared in deionized water according to the experimental design (Table 1). In order to prepare Ag nanoparticles, a $400 \mu \mathrm{L}$ adequate $\mathrm{AgNO}_{3}$ solution was added to $100 \mathrm{ml}$ starch solution of desired concentration (Table 1) and then adjusting the $\mathrm{pH}$ mixture on the desired value by adding an adequate solution of $\mathrm{NaOH}$ or $\mathrm{HNO}_{3}$ to the prepared mixture (Table 1).

The mixture was magnetically stirred at a fixed speed. The mixture presented a pale yellow color after nearly one minute, indicating the initial step of Ag-nanoparticles formation.

The experiment was runed at various $\mathrm{pHs}$, various silver nitrate concentrations, various starch concentrations and various times according to Table 
1 , in order to obtain the optimum conditions for synthesizing the Ag nanoparticles (Table 1).

To deal with the reaction time, we run the experiment and took the UV-visible spectra at various times respect to the initial time (Figs. 1and 2).

The formation of $\mathrm{Ag}$ nanoparticles was followed by the surface plasmon resonance (SPR) and as can be seen from the Fig. 1 the SPR band was increased with the reaction time.

The effect of solution $\mathrm{pH}$ on the $\mathrm{Ag}$ nanoparticles formation was studied and the results are shown in Fig. 2. The Ag nanoparticles formation at pHs lower than 9 was not favorable, but at a fairly higher $\mathrm{pH}$ was favorable. This may be due to the deprotonation of hydroxyl group of starch. Indeed, the charge transfers of hydroxyl group takes place easier in alkaline media. 5

\section{The adsorption process}

The adsorption of MO from aqueous solution onto Ag nanoparticles was performed in a static mode. Experiments were performed according to the first central composite design (CCD) matrix as expert design. In all stages, for investigating the influences of variables and evaluation of their interaction, $100 \mathrm{ml}$ of $\mathrm{MO}$ solution with constant initial concentration and $\mathrm{pH}$, was mixed with known adsorbent dose and stirred for different time at 400rpm. The mixture was agitated in an orbital shaker at room temperature at desired speed. Finally, mixture was separated by centrifugation at $4000 \mathrm{rpm}$ for $10 \mathrm{~min}$. The residual concentration was determined using Jusco UVVisible spectrophotometer model V-530 $\mathrm{nm}$. The response (removal efficiency or removal percentage, $\mathrm{Y}(\%)$ ) of $\mathrm{MO}$ was calculated as:

$$
\mathrm{Y}(\%)=\frac{\left(\mathrm{C}_{0}-\mathrm{C}_{\mathrm{t}}\right)}{\mathrm{C}_{0}} \times 100
$$

where and are initial and residual concentration of $\mathrm{MO}$ respectively.

In all experiments and stages, the final concentration of $\mathrm{MO}$ was evaluated using calibration curve obtained at the same conditions. Removal percentage, $Y \%$, for each run was calculated and optimum values of Silver nitrate concentration, starch solution concentration, $\mathrm{pH}$ and contact time were determined and reported in Table 3.

\section{RESULTS AND DISCUSSION}

\section{Model equation}

According to the four applied variable CCD experimental designs, 30 experiments including six replicates at the center point were performed to optimize the conditions and other points (according to Table 1). The obtained values of MO removal were entered in "Design Expert" software (as response) and quadratic model was selected to fit results for dye removal. A polynomial function respect to the $\mathrm{pH}(\mathrm{X} 1)$, starch concentration (X2), Silver nitrate concentration (X3) and reaction time $(X 4)$ for calculating the percentage of $\mathrm{MO}$ removal is presented in the eq. (2).

$\because$ MO removal- $219.84-28.8 X_{1}-36.4 X_{2}-238.1 X_{3}+0.27 X_{4}+1.76 X_{1}^{2}-297.96 X_{2}^{2}+$ $52.04 X_{3}^{2}-0.038 X_{4}^{2}-15 X_{1} X_{2}-0.031 X_{1} X_{4}+1200 X_{2} X_{3}+5.63 X_{2} X_{4}+0.63 X_{3} X_{4}$

The three dimensional response surface plots of the quadratic model (eq. 2) were drawn to show the effect of the variables on the efficient of prepared nanoparticle on the dye removal.

\section{Adsorption Kinetics}

One of the essential requirements for the proper interpretation of the experimental data obtained during kinetic studies is to identify the step(s) governing overall rate of removal during the 6

adsorption process41-43. The three flowering steps are thought to be involved during the adsorption of any organic or inorganic compounds over the surface of adsorbent:

a. Transport of adsorbate to the surface of the adsorbent, call film diffusion,.

b. Transport of the adsorbate within the pores of the adsorbent, call particle diffusion,.

c. Adsorption of adsorbate on the interior surface of the adsorbent.

The kinetics of adsorption process is an indicating factor controlling the efficiency of the process and the equilibrium time and showing the rate of adsorption uptake on Ag-NPs-AC(silver 
Table 1: Experimental design parameters for green synthesis of silver nanoparticles with starch solution*

\begin{tabular}{|c|c|c|c|c|c|}
\hline Assay & $\mathrm{X} 1$ & $\times 2$ & $x 3$ & $X 4$ & Response \\
\hline 1 & -1 & -1 & -1 & -1 & 65 \\
\hline 2 & 1 & -1 & -1 & -1 & 63 \\
\hline 3 & -1 & 1 & -1 & -1 & 71 \\
\hline 4 & 1 & 1 & -1 & -1 & 70 \\
\hline 5 & -1 & -1 & 1 & -1 & 65 \\
\hline 6 & 1 & -1 & 1 & -1 & 66 \\
\hline 7 & -1 & 1 & 1 & -1 & 66 \\
\hline 8 & 1 & 1 & 1 & -1 & 68 \\
\hline 9 & -1 & -1 & -1 & 1 & 74 \\
\hline 10 & 1 & -1 & -1 & 1 & 77 \\
\hline 11 & -1 & 1 & -1 & 1 & 78 \\
\hline 12 & 1 & 1 & -1 & 1 & 74 \\
\hline 13 & -1 & -1 & 1 & 1 & 68 \\
\hline 14 & 1 & -1 & 1 & 1 & 69 \\
\hline 15 & -1 & 1 & 1 & 1 & 70 \\
\hline 16 & 1 & 1 & 1 & 1 & 77 \\
\hline 17 & -2 & 0 & 0 & 0 & 74 \\
\hline 18 & 2 & 0 & 0 & 0 & 71 \\
\hline 19 & 0 & -2 & 0 & 0 & 67 \\
\hline 20 & 0 & 2 & 0 & 0 & 65 \\
\hline 21 & 0 & 0 & -2 & 0 & 62 \\
\hline 22 & 0 & 0 & 2 & 0 & 65 \\
\hline 23 & 0 & 0 & 0 & -2 & 63 \\
\hline 24 & 0 & 0 & 0 & 2 & 65 \\
\hline 25 & 0 & 0 & 0 & 0 & 70 \\
\hline 26 & 0 & 0 & 0 & 0 & 75 \\
\hline 27 & 0 & 0 & 0 & 0 & 65 \\
\hline 28 & 0 & 0 & 0 & 0 & 66 \\
\hline 29 & 0 & 0 & 0 & 0 & 71 \\
\hline 30 & 0 & 0 & 0 & 0 & 64 \\
\hline
\end{tabular}

${ }^{*} \mathrm{X}_{1}, \mathrm{X}_{2}, \mathrm{X}_{3}$ and $\mathrm{X}_{4}$ are four independent variables respectively: $\mathrm{pH}$, starch concentration, $\mathrm{AgNO}_{3}$ solution concentration and time of agitation. Their ranges and levels are shown in the table.

Table 2: Experimental range and levels of independent variables

\begin{tabular}{llllll}
\hline Parameters & \multicolumn{5}{l}{ Factors } \\
\hline Range and levels (coded) & -2 & -1 & 0 & 1 & 2 \\
$\mathrm{pH}$ & 7 & 8 & 9 & 10 & 11 \\
Starch concentration(W\%) & 0.05 & 0.1 & 0.15 & 0.2 & 0.25 \\
Silver nitrate concentration(M) & 0.05 & 0.1 & 0.15 & 0.2 & 0.25 \\
Time of reaction(h) & 4 & 8 & 12 & 16 & 24 \\
\hline
\end{tabular}


nanoparticles loaded on activated carbon)44. In order to identify the potential rate controlling steps involved in the process of adsorption, three kinetic models were used to fit the experimental data of the dye adsorption; including pseudo first- and pseudo second- order, Elovich kinetic as well as intraparticle diffusion models onto Ag-NPs-AC45.

Table 3: Process optimum conditions and the results

\begin{tabular}{lccccc}
\hline Case & Target & $\mathrm{pH}$ & $\mathrm{C} \mathrm{Ag+/(mol/L)}$ & $\mathrm{C}$ starch $/ \mathrm{w} \%$ & Time (h) \\
\hline Dye Removal & optimized & 11 & 0.05 & 0.05 & 4 \\
\hline
\end{tabular}

Table 4: Kinetic parameters for MO removing onto synthesized Ag-NPs-AC as adsorebent

\begin{tabular}{|c|c|c|c|c|c|c|c|}
\hline \multirow[t]{2}{*}{ Model } & \multirow{2}{*}{$\begin{array}{l}\text { Parameter } \\
\mathrm{C}(\mathrm{MO})\end{array}$} & \multicolumn{3}{|c|}{$0.008 \mathrm{~g}$ of adsorbent } & \multicolumn{3}{|c|}{$0.025 \mathrm{~g}$ of adsorbent } \\
\hline & & $5 \mathrm{mg} / \mathrm{L}$ & $25 \mathrm{mg} / \mathrm{L}$ & $50 \mathrm{mg} / \mathrm{L}$ & $5 \mathrm{mg} / \mathrm{L}$ & $25 \mathrm{mg} / \mathrm{L}$ & $50 \mathrm{mg} / \mathrm{L}$ \\
\hline \multirow[t]{3}{*}{ First-order kinetic } & $\mathrm{k}_{1}$ & 0.02 & 0.0235 & 0.0301 & 0.037 & 0.022 & 0.004 \\
\hline & $\mathrm{qe}(\mathrm{cal})^{*}$ & 194.58 & 245.64 & 549.03 & 55.31 & 516.4 & 250.4 \\
\hline & $\mathrm{R}^{2}$ & 0.8499 & 0.8494 & 0.9314 & 0.957 & 0.932 & 0.943 \\
\hline \multirow[t]{3}{*}{ Second-order kinetic } & $k^{2} \times 10^{-4}$ & 0.524 & 0.325 & 0.832 & 7.32 & 0.134 & 0.124 \\
\hline & $\mathrm{qe}(\mathrm{cal})^{*}$ & 222 & 303 & 833.33 & 56.82 & 434.8 & 263.1 \\
\hline & $\mathrm{R}^{2}$ & 0.7547 & 0.8945 & 0.9959 & 0.994 & 0.928 & 0.912 \\
\hline \multirow[t]{3}{*}{ Intraparticle diffusion } & $k_{d i f f} f$ & 13.54 & 17.665 & 43.31 & 3.62 & 19.40 & 22.50 \\
\hline & $\mathrm{C}^{\text {dif }}$ & 16.30 & 27.30 & 279.94 & 9.87 & 36.92 & 44.16 \\
\hline & $\mathrm{R}^{2}$ & 0.945 & 0.9851 & 0.9502 & 0.956 & 0.975 & 0.932 \\
\hline \multirow[t]{3}{*}{ Elovich } & $\beta$ & 0.0202 & 0.019 & 0.0074 & 0.085 & 0.012 & 0.008 \\
\hline & $\alpha$ & 1 & 8.47 & 24.94 & 24.19 & 27.6 & 35.4 \\
\hline & $\mathrm{R}^{2}$ & 0.798 & 0.9031 & 0.999 & 0.982 & 0.935 & 0.945 \\
\hline qe $(\exp )^{\star}$ & & 154.4 & 179.92 & 738.76 & 47.8 & 247.3 & 215.7 \\
\hline
\end{tabular}

Table 5: Langmuir isotherm parameters for MO adsorption onto the Ag-NPs-AC Langmuir

\begin{tabular}{lll}
\hline Model & Parameter & Experimental Data \\
\hline ittereration-1: $\mathrm{C}_{\mathrm{e}} / \mathrm{q}_{\mathrm{e}}=\left(1 / \mathrm{K}_{\mathrm{a}} \mathrm{Q}_{\mathrm{m}}\right)+\mathrm{C}_{\mathrm{e}} / \mathrm{Q}_{\mathrm{m}}$ & $\mathrm{Q}_{\mathrm{m}}(\mathrm{mg} / \mathrm{g})$ & 66.67 \\
& $\mathrm{~K}_{\mathrm{a}}\left(\mathrm{L} \mathrm{mg} \mathrm{mg}^{-1}\right)$ & 0.17 \\
& $\mathrm{R}^{2}$ & 0.99 \\
& $\mathrm{Q}_{\mathrm{m}}(\mathrm{mg} / \mathrm{g})$ & 63.3 \\
& $\mathrm{~K}_{\mathrm{a}}(\mathrm{L} \mathrm{mg})$ & 0.19 \\
& $\mathrm{R}^{2}$ & 0.998 \\
itteration-2: $1 / \mathrm{q}_{\mathrm{e}}=1 /\left(\mathrm{K}_{\mathrm{a}} \mathrm{Q}_{\mathrm{m}} \mathrm{C}_{\mathrm{e}}\right)+1 / \mathrm{Q}_{\mathrm{m}}$ & $\mathrm{Q}_{\mathrm{m}}(\mathrm{mg} / \mathrm{g})$ & 63.22 \\
& $\mathrm{~K}_{\mathrm{a}}\left(\mathrm{L} \mathrm{mg}{ }^{-1}\right)$ & 0.191 \\
& $\mathrm{R}^{2}$ & 0.972 \\
& $\mathrm{Q}_{\mathrm{m}}(\mathrm{mg} / \mathrm{g})$ & 64.16 \\
& $\mathrm{~K}_{\mathrm{a}}(\mathrm{L} \mathrm{mg}-1)$ & 0.1856 \\
& $\mathrm{R}^{2}$ & 0.972 \\
\hline
\end{tabular}


The pseudo-first order kinetic model (Fig. 9) can be represented by the following Lagergen rate equation 46 :

$$
\log \left(q_{e}-q_{t}\right)=\log q_{e}-\left(k_{1}-2.303 t\right)
$$

where and are the amounts of adsorbed adsorbate $(\mathrm{mg} / \mathrm{g})$ onto the adsorbent at equilibrium and at contact time $(\mathrm{t})$, respectively, and is the pseudo- first-order rate constant (min-1). The values of and can be evaluated from the intercept and slope of eq.(3). The experimental values of were not close to the calculated ones. It suggests that the kinetics of MO adsorption onto Ag-NPs-AC did not satisfactorily control by the pseudo first-order model and, hence, cannot be a diffusion controlled phenomenon.

The pseudo-second-order kinetic model eq.(4) (Fig.10) was tested and showed a good agreement with the experimental data (table 4)

$$
\frac{t}{q_{t}}=\left(\frac{1}{k_{2} q_{e}^{2}}\right)+\left(\frac{1}{q_{e}}\right) t
$$

where $k_{2}$ is the rate constant of pseudosecond-order adsorption $(\mathrm{g} /(\mathrm{mg} \mathrm{min}))$.

Table 6: Calculated isotherm constants and correlation coefficients for MO adsorption onto the silver nanoparticles loaded on AC

\begin{tabular}{lll}
\hline Model & Parameter & Experimental Data \\
\hline Langmuir-iteration2: $1 / \mathrm{q}_{\mathrm{e}}=1 /\left(\mathrm{K}_{\mathrm{a}} \mathrm{Q}_{\mathrm{m}} \mathrm{C}_{\mathrm{e}}\right)+1 / \mathrm{Q}_{\mathrm{m}}$ & $\mathrm{Qm}(\mathrm{mg} / \mathrm{g})$ & 63.3 \\
& $\mathrm{Ka}(\mathrm{L} \mathrm{mg})$ & 0.19 \\
& $\mathrm{R}^{2}$ & 0.998 \\
Freundlich: $\ln \mathrm{q}_{\mathrm{e}}=\ln \mathrm{KF}+(1 / \mathrm{n}) \ln \mathrm{C}_{\mathrm{e}}$ & $1 / \mathrm{n}$ & 0.57 \\
& $\mathrm{KF}(\mathrm{L} / \mathrm{mg})$ & 2.82 \\
& $\mathrm{R}^{2}$ & 0.976 \\
Temkin: $\mathrm{q}_{\mathrm{e}}=\mathrm{B}_{1} \ln \mathrm{KT}+\mathrm{B} 1 \ln \mathrm{C}_{\mathrm{e}}$ & $\mathrm{B}_{1}$ & 13.75 \\
& $\mathrm{KT}(\mathrm{L} / \mathrm{mg})$ & 1.99 \\
Harkins-Jura $(\mathrm{H}-\mathrm{J}): 1 / \mathrm{q}_{\mathrm{e}}{ }^{2}=\left(\mathrm{B}_{2} / \mathrm{A}\right)-(1 / \mathrm{A}) \log \mathrm{Ce}$ & $\mathrm{R}^{2}$ & 0.983 \\
& $\mathrm{~A}$ & 105.26 \\
& $\mathrm{~B}^{2}$ & 1.04 \\
Dubinin and Radushkevich $(\mathrm{D}-\mathrm{R}): \operatorname{lnq} \mathrm{e}_{\mathrm{e}}=\ln \mathrm{Q}_{\mathrm{s}}-\mathrm{B} \varepsilon^{2}$ & $\mathrm{R}^{2}$ & 0.676 \\
& $\mathrm{Qs}(\mathrm{mg} / \mathrm{g})$ & 37.49 \\
& $\mathrm{~B}(\mathrm{kj} / \mathrm{mol})=1 /(2 \mathrm{~B})^{1 / 2}$ & $4 \mathrm{E}-07$ \\
& $\mathrm{R}^{2}$ & 0.852 \\
\hline
\end{tabular}

In addition, we examined Elovich equation (eq. 5 and Fig. 11) for representing our experimental data (see table 4)

$$
q_{t}=\left(\frac{1}{\beta}\right) \ln (\alpha \beta)+\left(\frac{1}{\beta}\right) \ln (t)
$$

where $\alpha$ is the initial adsorption rate (mg/ ( $(\mathrm{min})$ ), and $\beta$ is the desorption constant related to the extend of surface coverage and activation energy for chemisorption $(\mathrm{g} / \mathrm{mg})$.
Finally, we pay attention to the intraparticle diffusion model (eq. 6)

$$
q_{t}=k_{i d} t^{\frac{1}{2}}+C
$$

where $k_{i d}$ is the intraparticle diffusion rate constant ( $\mathrm{mg} / \mathrm{g} \mathrm{min} 1 / 2)$ and $C$ is the intercept. If the mechanism of adsorption process follows the intraparticle diffusion, the plot of $\mathrm{q}_{\mathrm{t}}$ versus $\mathrm{t} 1 / 2$ should be a straight line and $k_{i d}$ and $C$ can be calculated 
from the slope and intercept of the plot (Fig.12). The values of $C$ give an idea about the thickness of the boundary layer, i.e., the larger the intercept leads to the larger rate-controlling step ${ }^{47,48}$.

In order to study the effect of other conditions such as initial concentration of dye or the amount of adsorbent dosage on dye removal, we selected two dosages $(0.008 \mathrm{~g}$ and $0.025 \mathrm{~g})$ of adsorbent and three various initial concentration of dye ( Experimental data reported in Table 4).

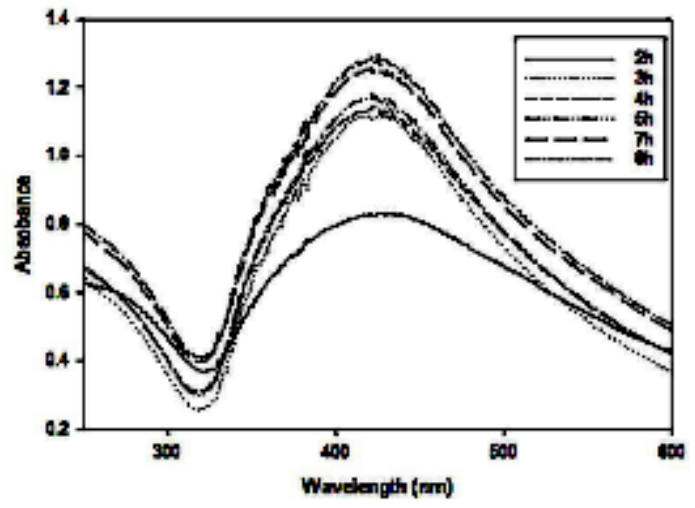

Fig. 1: Evolution of UV-visible absorption spectra after addition of AgNO3 solution into the soluble starch solution ; conditions: $\mathrm{AgNO}_{3}$ solution $0.05 \mathrm{M}$ and Starch W\% 0.05, $\mathrm{pH}=11$ and Temperature $60^{\circ} \mathrm{C}$

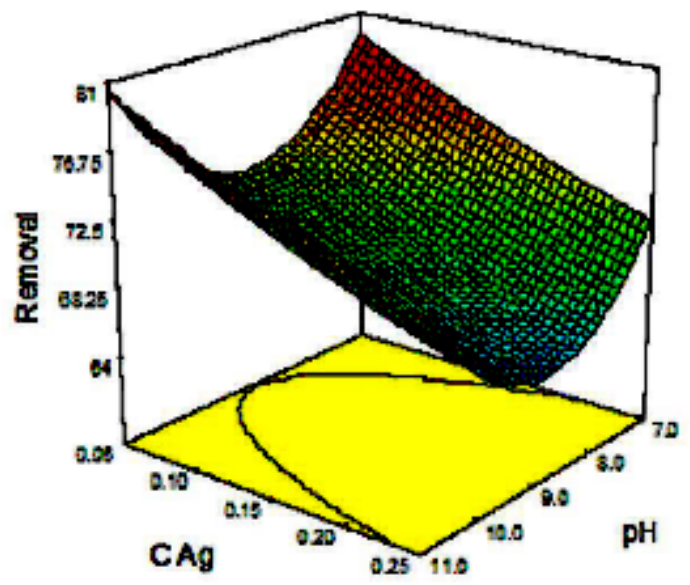

Fig. 3: Three dimensional plot showing the effect of silver nitrate concentration and $\mathrm{pH}$ couple on efficiency of synthesized Ag-NPs-AC for the MO removal

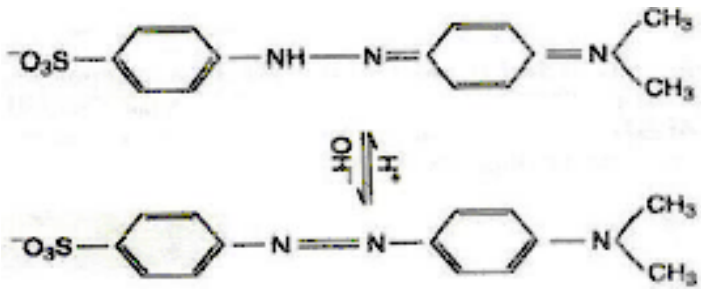

Scheme 1: Chemical change of Methyl Orange structure by $\mathrm{pH}$

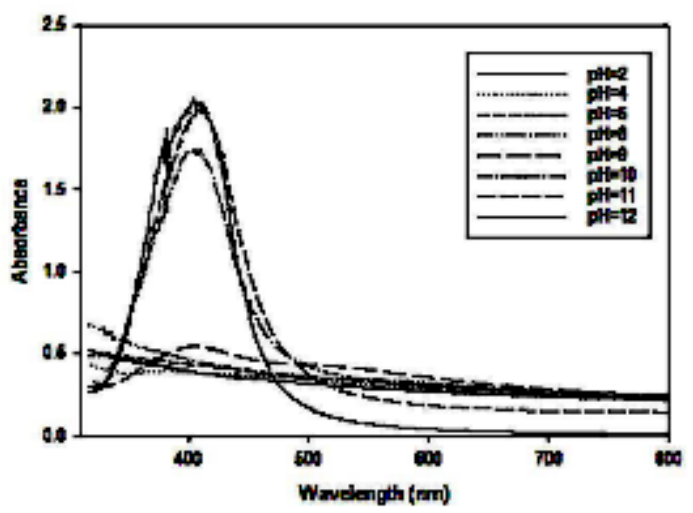

Fig. 2: Evolution of UV-visible absorption spectra after addition of AgNO3 solution into the soluble starch solution at various $\mathrm{pHs}$; conditions: AgNO3 solution $0.05 \mathrm{M}$, and Starch W\% 0.05, pH, 2 up to 12 and Temperature $60^{\circ} \mathrm{C}$

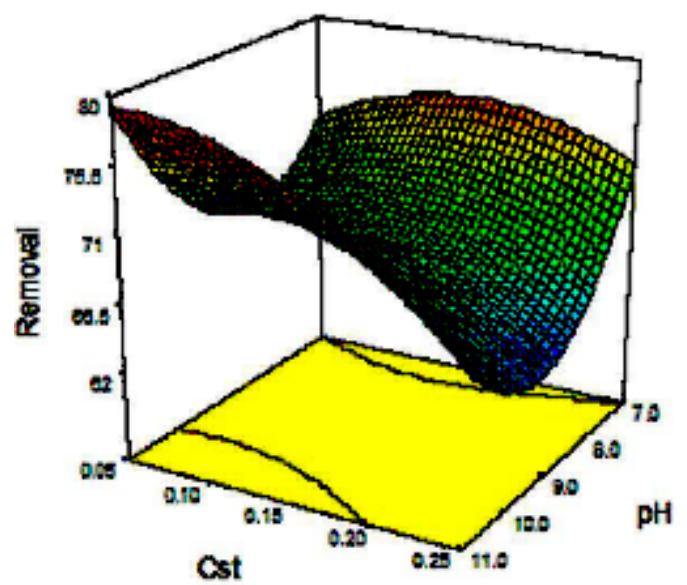

Fig. 4: Three dimensional plot showing the effect of starch solution concentration and $\mathrm{pH}$ couple on efficiency ofsynthesized Ag-NPs-AC for the MO removal 


\section{Adsorption isotherms}

The equilibrium data that commonly known as adsorption isotherms, describe how the adsorbate interacts with adsorbent, and give a comprehensive understanding of the nature of interaction. It is basically important to optimize the design of an adsorption system. The obtained parameters from the different models provide important information on the surface properties of the adsorbent and its affinity to the adsorbate. Several isotherm equations have been developed and employed for such an

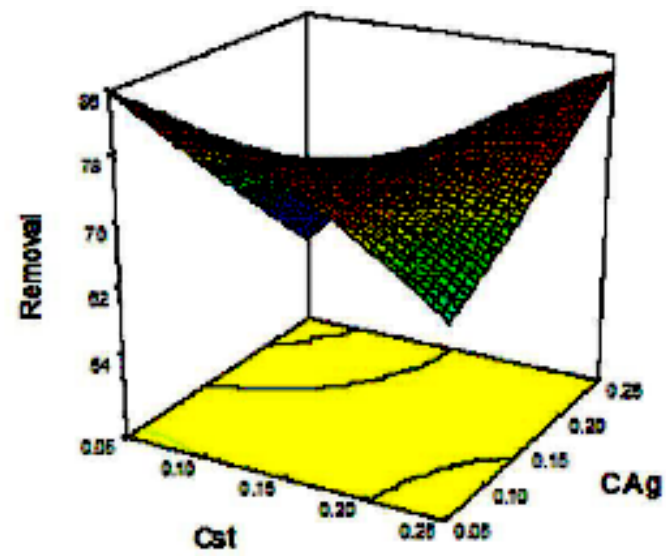

Fig. 5: Three dimensional plot showing the effect of silver nitrate concentration and starch solution concentration couple on efficiency of synthesized Ag-NPs-AC for the MO removal

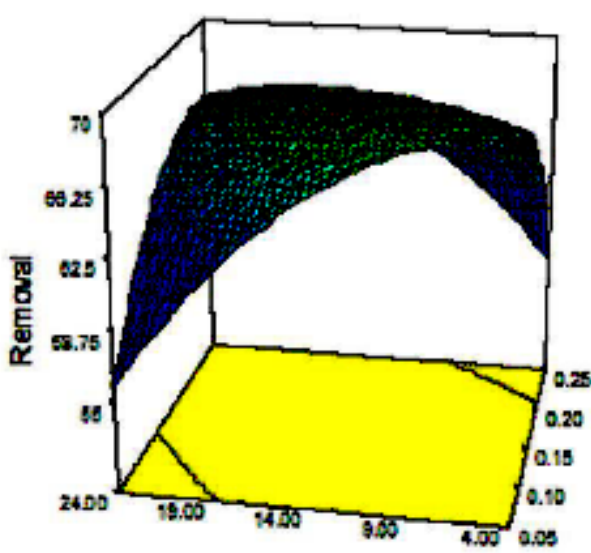

$t$ (h)

Fig. 7: Three dimensional plot showing the effect of starch solution concentration and reaction time couple on efficiency of synthesized Ag-NPs-AC for the MO removal analysis, and the 3 important isotherms, the Langmuir (Figs. 13-16 and Table 5), Freundlich (Fig. 17) and Temkin (Fig. 18) isotherms were applied to fit experimental data (Table 6).

\section{Some important results}

Indeed, this research consists of two parts; one, Ag nanoparticles synthesis, and the other, thermodynamic and kinetic interpretation of the adsorption process of $\mathrm{MO}$ adsorption onto the synthesized nanoparticles.

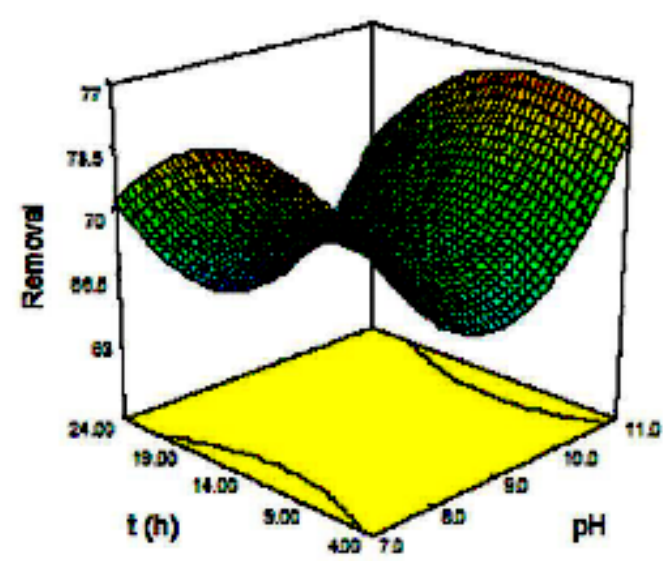

Fig. 6: Three dimensional plot showing the effect of $\mathrm{pH}$ and reaction time couple on efficiency of synthesized Ag-NPs-AC for the MO removal

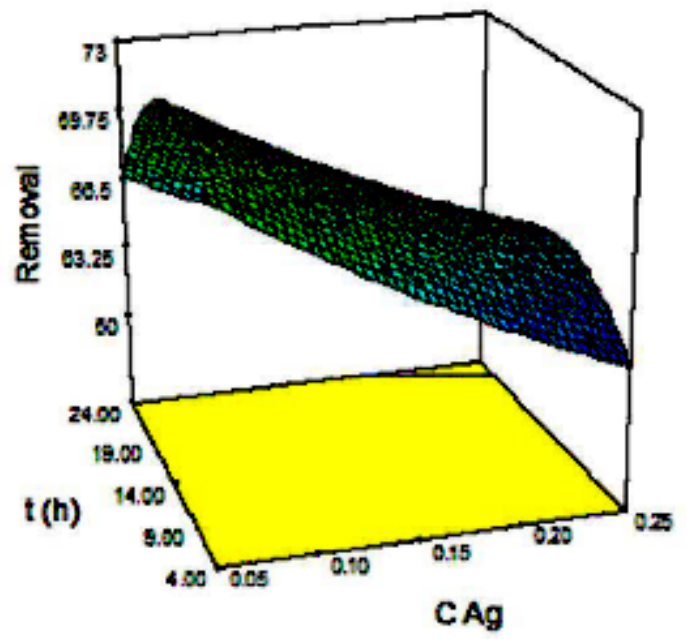

Fig. 8. Three dimensional plot showing the effect of silver nitrate solution concentration and reaction time coupleon efficiency of synthesized Ag-NPs-AC for the MOremoval. 
The Ag-NPs synthesis was carried out under the conditions of tables 1 and 2, and the obtained optimum conditions are reported in table 3. The Figs. 3-8 show the effect of various couples of parameters, such as AgNO3 concentration - $\mathrm{pH}$ couple, starch solution - $\mathrm{pH}$ couple and so on, on the efficiency of synthesized Ag-NPs-AC for the dye removal.

The results of kinetic and thermodynamic experiments are gathered in tables 4-6 and represented graphically in Figs. 9-18.

Fig. 3 shows the effect of $\mathrm{AgNO}_{3}$ concentration and $\mathrm{pH}$ on the efficiency of

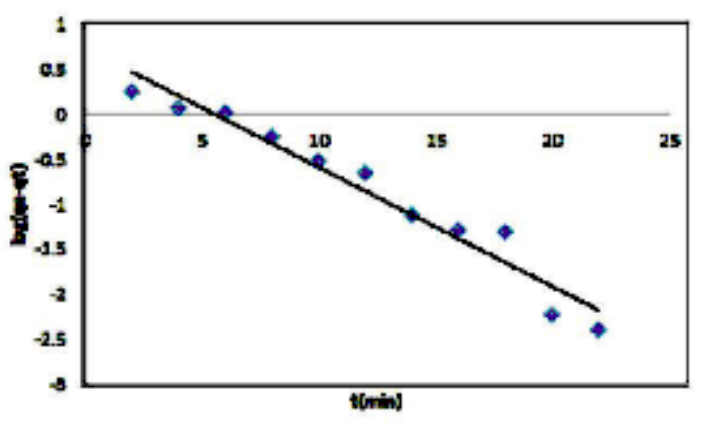

Fig. 9: Pseudo-first-order kinetics for the adsorption of methyl orange onto the silver nanoparticles loaded on $\mathrm{AC}$; conditions: $\mathrm{pH}=3$ adsorbent dosage $0.1 \mathrm{~g}, \mathrm{CO}=25 \mathrm{mgL}^{-1}$ at room temperature

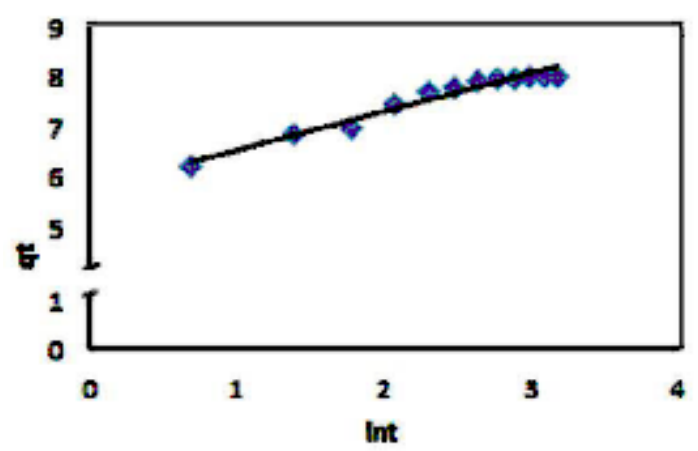

Fig. 11: Elovich kinetic for the adsorption of methyl orange onto the silver nanoparticles loaded on $\mathrm{AC}$; conditions: $\mathrm{pH}=3$ adsorbent dosage $0.1 \mathrm{~g}, \mathrm{C} 0=25 \mathrm{mgL}^{-1}$ at room temperature synthesized Ag-NPs-AC for the dye removal. Increasing the AgNO3 concentration at pHe"9, provided an increased in the dye removal percentage.

Fig. 4 shows the effect of starch solution and solution $\mathrm{pH}$ couple on the efficiency of Ag-NPs$\mathrm{AC}$ for the dye removal. The lower concentration of starch and higher $\mathrm{pH}$ lead to the better dye removal.

After Fig. 5, the lower concentration of the two considered solutions gives a better efficiency.

Fig. 6 is connected to the pair interaction of $\mathrm{pH}$ and time. With "higher $\mathrm{pH}$-lower time" and

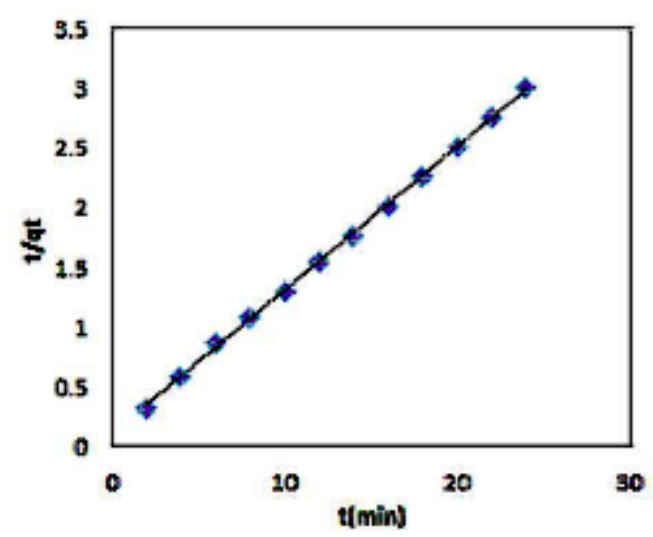

Fig. 10. Pseudo-second-order kinetics for the adsorption of methyl orange onto the silver nanoparticles loaded on $\mathrm{AC}$; conditions: $\mathrm{pH}=3$ adsorbent dosage $0.1 \mathrm{~g}, \mathrm{C} 0=25 \mathrm{mgL}-1$ at room temperature

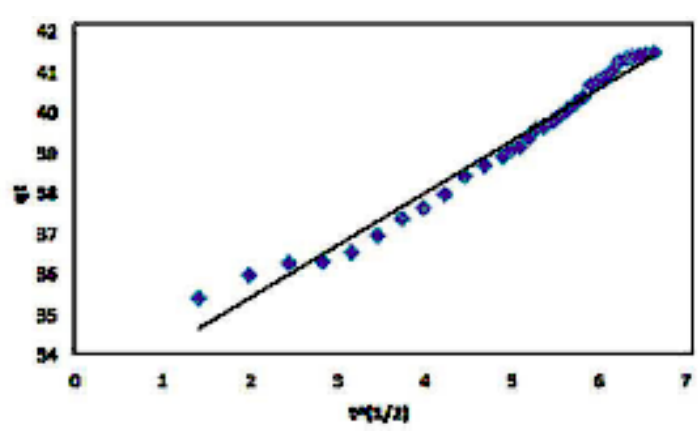

Fig. 12: Intraparticle diffusion for the adsorption of methyl orange onto the silver nanoparticles loaded on $\mathrm{AC}$; conditions: $\mathrm{pH}=3$ adsorbent dosage $0.1 \mathrm{~g}, \mathrm{CO}=25 \mathrm{mgL}^{-1}$ at room temperature 


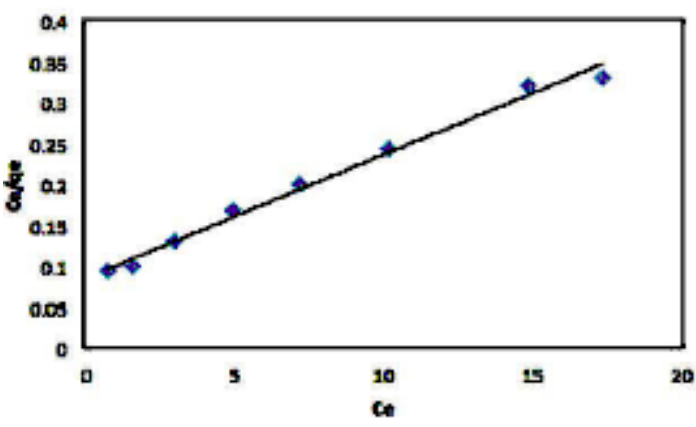

Fig. 13: The Langmuir isotherm for the adsorption of methyl orange onto the silver nanoparticles loaded on AC(iteration 1 ) ; conditions: $\mathrm{pH}=3$ adsorbent dosage $0.1 \mathrm{~g}, \mathrm{CO}=$ $25 \mathrm{mgL}^{-1}$ at room temperature

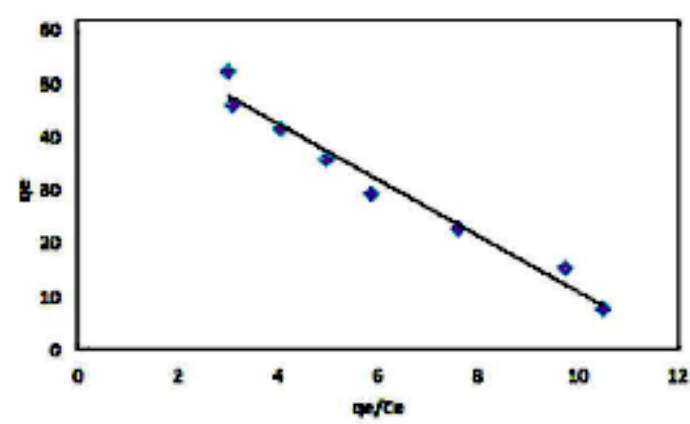

Fig. 15: The Langmuir isotherm for the adsorption of methyl orange onto the silver nanoparticles loaded on AC(iteration 3) ; conditions: $\mathrm{pH}=3$ adsorbent dosage $0.1 \mathrm{~g}, \mathrm{CO}=$ $25 \mathrm{mgL}^{-1}$ at room temperature

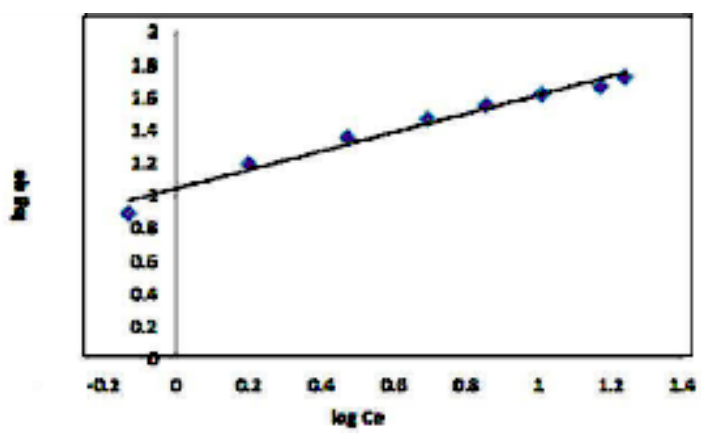

Fig. 17: Freundlich isotherm for the adsorption of methyl orange onto the silver nanoparticles loaded on $\mathrm{AC}$; conditions: $\mathrm{pH}=3$ adsorbent dosage $0.1 \mathrm{~g}, \mathrm{C} 0=25 \mathrm{mgL}^{-1}$ at room temperature

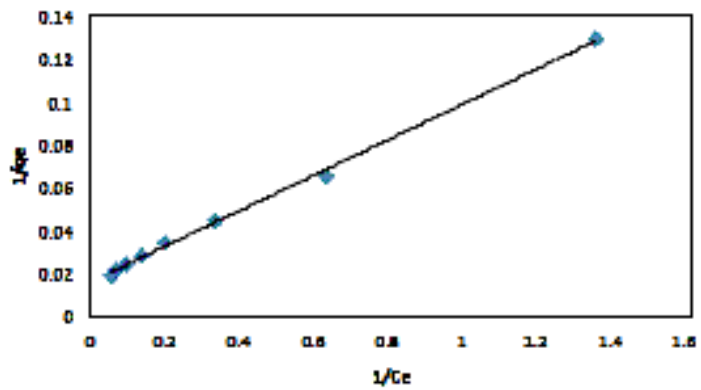

Fig. 14: Langmuir isotherm for the adsorption of methyl orange onto the silver nanoparticles loaded on AC(iteration 2) ; conditions: $\mathrm{pH}=3$ adsorbent dosage $0.1 \mathrm{~g}, \mathrm{CO}=25 \mathrm{mgL}^{-1}$ at room temperature

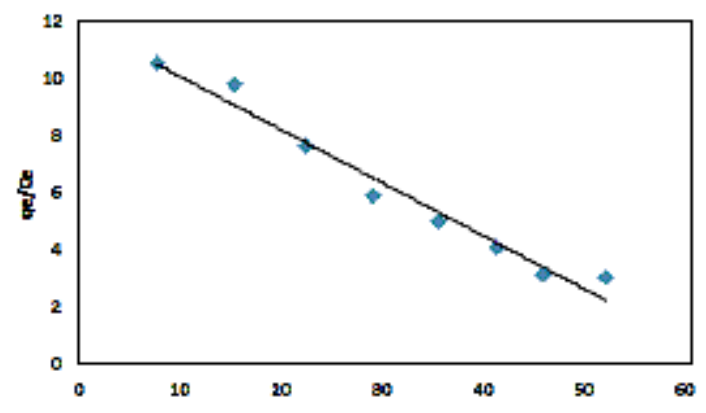

Fig. 16: The Langmuir isotherm for the adsorption of methyl orange onto the silver nanoparticles loaded on AC(iteration 4) ; conditions: $\mathrm{pH}=3$ adsorbent dosage $0.1 \mathrm{~g}, \mathrm{C} 0=$ $25 \mathrm{mgL}^{-1}$ at room temperature

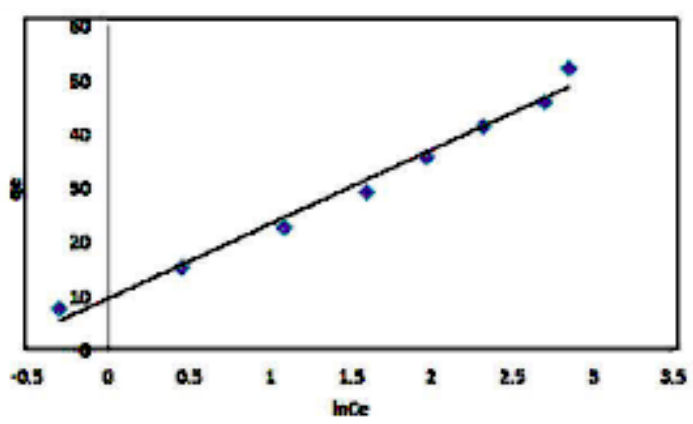

Fig. 18: Temkin isotherm for the adsorption of methyl orange onto the silver nanoparticles loaded on $\mathrm{AC}$; conditions: $\mathrm{pH}=3$ adsorbent dosage $0.1 \mathrm{~g}, \mathrm{CO}=25 \mathrm{mgL}^{-1}$ at room temperature 
"lower pH-higher time" the efficiency of Ag-NPs$A C$ for the dye removal is better.

Addressing to Fig. 7, we see that the lower concentration of starch with a short time is better conditions for synthesizing Ag-NPs-AC for the dye removal. Fig. 8 shows that upon increasing in the AgNO3 concentration, the percentage of dye removal becomes more satisfactory.

\section{CONCLUSION}

Synthesized silver nanoparticles by starch solution and loaded onto activated carbon (from olive stone) appeared to be an excellent adsorbent for removal methyl orange dye from aqueous solutions. The effect of experimental parameters such as $\mathrm{pH}$ range reagent concentration, contact time, dosage amount of adsorbent and so on, on the behavior and efficiency of synthesized Ag-NPs$A C$ and the adsorption process were investigated and the resultant values were kinetically better consistent with the pseudo second order reaction and Elovich model and thermodynamically to the Langmuir, Freundlich and Temkin models. Langmuir model fitted better our experimental results.

\section{REFERENCES}

1. Mohan S. V, Roa C N, Prasad K K and Karthikeyan J, Waste Manage., 2002, 22, 575-582.

2. M. Ghaedi, et al., J. Ind. Eng. Chem. (2012), http://dx.doi.org/10.1016/j.jiec.2012.08.006

3. C. Moreno-Castilla, F. Carrasco-Mar1'n, M.V. Lo'pez-Ramo'n, M.A. A ' Ivarez-Merino, Carbon 2001, 39, 1415.

4. D. Lozano-Castello, M.A. Lillo-Ro'denas, D. Cazorla-Amoro s, A. Linares-Solano, Carbon 2001, 39, 741.

5. M.A. Lillo-Ro'denas, D. Lozano-Castello' , D. Cazorla-Amoro's, A. Linares-Solano, Carbon 2001, 39, 751.

6. G.H. Oh, C.R. Park, Fuel 2002, 81, 327.

7. M.A. Lillo-Ro'denas, D. Cazorla-Amoro's, A. Linares-Solano, Carbon 2003, 41, 267.

8. Ghosh .D and B.hattacharyya, KG, Appl Clay Sci., 2002, 20, 295-300.

9. Bulut .E, Ozacar .M and Sengil .I. A, J Hazard Mater., 2008, 154, 613-622.

10. M. Ghaedi, S. J. Hosseini and S. Ramezani, Platinum Nanoparticles Loaded on Activated Carbonas Novel Adsorbent for the Removal of Congo Red,http://www.ejournals.net, E-Journal of Chemistry 2012, 9(1), 63-74. 9

11. T. Robinson, G. Mcmullan, R. Marchant, P. Nigam, Remediation of dyes in textile effluent: a critical review on current treatment technologies with a proposedalternative, Bioresour. Technol. 2001, 77, 247-255.

12. R.-S. Juang, R.-L.Tseng, F.-C.Wu, S.-
H.Lee,Adsorptionbehaviour of reactive dyesfrom aqueous solutions on chitosan, $\mathrm{J}$. Chem. Technol. Biotechnol. 1997, 70, 391399.

13. S. Karcher, A. Kornmuller, M. Jekel, Removal of reactive dyes by sorption/complexation with cucurbituril,Water Sci. Technol. 1999, 40, 425-433.

14. Z. Aksu, S. Tezer, Equilibrium and kinetic modelling of biosorption of RemazolBlack $B$ by $R$. arrhizus in a batch system: effect of temperature, Process Biochem. 2000, 36, 431-439.

15. T. O'Mahony, E. Guibal, J.M. Tobin, Reactive dye biosorption by Rhizopusarrhizus biomass, Enzyme Microbial Technol. 2002, 31, 456-463.

16. R.B. Venkata, C.A. Sastray, Removal of dyes from aqueous solutions by cellulosicwaste orange peel, Indian J. Environ. Prot. 1987, 7, 363-376.

17. F. Yuzhu, T. Viraraghavan, Dye biosorption sites in Aspergillus niger, Bioresour. Technol. 2002, 82, 139-145.

18. Kucukosmanoglu, M., Gezici, O. and Ayar, A., Theadsorption behaviors of methylene blue and methyl orange ina diaminoethanesporopollen in mediated column system. Sep.Purif. Technol. 2006, 52 (2), 280-287.

19. Chang, R.W., Chadwick, J. Allison, J.C., Hayes, Y.O., Talley,D.L. and Autry, C.E., Microbial succession andintestinal enzyme 
activities in the developing rat. J. Appl. Bacteriol. 1994, 77(6), 709-718.

20. Chung, K.T., Stevens Jr. S.E. and Cerniglia, C.E., Thereduction of azo dyes by the intestinal microflora. Crit. Rev.Microbiol. 1992, 18(3), 175-190.

21. Chung, K.T., The significance of azoreduction in themutagenesis and carcinogenesis of azo dyes. Mutat. Res. 1983, 114(3), 269-281.

22. El Qada, E.N., Allena, S.J. and Walker, G.M. Adsorptionof basic dyes from aqueous solution onto activated carbons.Chem. Eng. J. 2008, 135(3), 174-184.

23. Namasivayam $\mathrm{C}$ and Kavitha D, Dyes Pigments, 2002, 54, 47-58.

24. Ghaedi. M, Zamani Amirabad .S, Marahel F, Nasiri Kokhdan S, Sahraei R andDaneshfar A, Spectrochim Acta Part A: Mol Biomol Spectrosc, 2011, 83, 46-51.

25. Chatterjee. S, Lee .D. S, Lee. M. W and Woo. S. H, Biores. Technol., 2009, 100, 28032809.

26. Malik. P. K and Saha. S. K, Sep Purif Technol., 2003, 31, 241-250.

27. Vogelpohl. A and Kim. S. M, J IndEng Chem., 2004, 10, 33-40.

28. Ciardelli. G, Corsi. L and Marussi. M, Resour Conserv Recycl., 2001, 31, 109-113.

29. Gopinath. K. P, Murugesan. S, Abraham J, Muthukumar. K and Bacillus. S. P, Bioresour Technol., 2009, 100, 6295-6300.

30. Orfao. J. J. M, Silva. A. I. M, Pereira. J. C. V, Barata. S. A, Fonseca. I. M, Faria. P. C. C and Pereira M F R, J CollInterf Sci., 2006, 296(2), 480-489.

31. Nandi. B. K, Goswami A and Purkait M K, J Hazard Mater., 2009, 161(1), 387-395.

32. Slejko. F. L, Adsorption Technology, New York, 1985.

33. Suffet. I. H and McGurie. M. J, Ann Arbor Sci Michigan, 1985, 1-2.

34. Jain. R. and Sikarwar. S, J Hazard Mater., 2008, 152, 942-948. 10

35. Kreyling. W, Parameters of nanoparticles determiningdistribution and accumulation in secondary targetorgans. Toxicol.Lett. 2007, 172, S35.http://dx.doi.org/10.1016/j.toxlet. 2007.05.121

36. Slawson. RM, Trevors. JT, Lee, H: Silver accumulation and resistance in Pseudomonas stutzeri. Arch. Microbiol. 1992, 158, 398-404.

37. Zhao. GJ, Stevens. SE: Multiple parameters for the comprehensive evaluationof the susceptibility of Escherichia coli to the silver ion. Biometals 1998, 11, 27-32.

38. Sukumaran Prabhu and Eldho. K. Poulose: Silver nanoparticles: mechanism of antimicrobialaction, synthesis, medical applications, andtoxicity effects, International Nano Letters 2012, 2; 32, http://www.inljournal.com/content/2/1/32

39. Raveendran. P, Fu. J, Wallen SL. J Am Chem Soc 2003;125, 13940.

40. Virender. K, Sharma. Ria A. Yngard, Yekaterina Lin:Silver nanoparticles: Green synthesis and their antimicrobial activities, Advances in Colloid and Interface Science 2009, 145, 83-96.

41. Ghaedi. M., Ghezelbash. GR., Marahel, F., Equilibrium, Thermodynamic, and Kinetic Studies on Lead (II) Biosorption from Aqueous Solution by Saccharomyces cerevisiaeBiomass. Clean-Soil Air Water. 2010, 38(9), 877-885.

42. M. Ghaedi, F. Karimi, B. Barazesh, R. Sahraei, A. Daneshfar: Removal of Reactive Orange 12 from aqueous solutions by adsorption on tinsulfide nanoparticle loaded on activated carbon, Journal of Industrial and Engineering Chemistry 2013, 19, 756-763

43. Lata. H., Garg, V.K., Gupta, R.K., Adsorptive removalof basic dye by chemically activated Parthenium biomass:equilibrium and kinetic modeling. Desalination. 2008, 219, 250-261.

44. M. Ghaedi, A. Ansari, M.H. Habibi, A.R. Asghari, Removal of malachite green from aqueous solution by zinc oxidenanoparticle loaded on activated carbon: Kinetics and isotherm study, Journal of Industrial and Engineering Chemistry 2014, 20, 17-28

45. S. Javad Hosseini, Syamak Nasiri Kokhdan1, A. Mohamad Ghaedi and S. Saman Moosavian, Comparison of multiwalled carbon nanotubes and activated carbon for efficient removal of Methyl Orange:Kinetic and Thermodynamic investigation. Fresenius Environmental Bulletin, 2010, 20(1a). 
46. Lagergren, S., Zurtheorie der sogenennten adsorption gelosterstoffe, Kungliga Svenskavetenskademiens. Handlingar, 1898, 24, 1-39.

47. Kavitha, D. and Namasivayam, C., Experimental andkinetic studies on methylene blue adsorption by coir pith carbon,Bioresour. Technol. 2007, 98(1), 1421.

48. Demirbas, E. and Nas, M.Z., Batch kinetic and equilibriumstudies of adsorption of
Reactive Blue 21 by fly ash andsepiolite. Desalination. 2009, 243(1-3), 8-21.

49. Aruna Jyothi Kora and Jayaraman Arunachalam, Green Fabrication of Silver Nanoparticles by Gum Tragacanth (Astragalus gummifer): A Dual Functional Reductant and Stabilizer; Hindawi Publishing Corporation Journal of Nanomaterials 2012, Article ID 869765, 8 pagesdoi:10.1155/2012/869765 